\title{
DENIAL OF EQUAL RIGHTS TO RELIGIOUS MINORI- TIES AND NON-BELIEVERS IN THE UNITED STATES
}

\author{
B. H. HARTOGENSIS
}

Equality of all men before the law, the ideal to which seers and philosophers have looked forward for ages, ${ }^{2}$ is far from being attained in the United States, despite such slogans as the "Rights of Man," "Freedom of Religion and of Conscience," "A Free State," "All Mren Are Created Equal," the First and Fourteenth Amendments to the Constitution, and the like. The Revolutionary War, so we are taught at school, separated Church and State, but that meant merely that the colonists were no longer subservient to the Church of England." For the purpose of putting an end to the arrogant "toleration" ${ }^{3}$ of religious

IA high ideal is that of the MTosaic law: "Ye shall have one manner of law as well for the stranger as for one of your own country." IEV. 24:22; cf. NIUNr. 15:29.

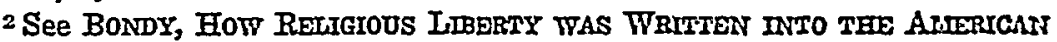
CoNsTHUTION (1927).

3 "Toleration-I am for freedom of religion against all manoeuvres to bring about a legal ascendancy of one sect over another." Thomas Jefferson. "The right of every man is to liberty,-not toleration." James Mradison.

Toleration may be defined as a favor granted by the dominant Christians to such' non-conformists as they graciously for the time being tolerate, ice, sufier and allow, as a superior does his inferior. Toleration is thas to be expressiy distinguished from religious liberty for all, which negatives a union of Church and State, and expressly denies anthority to enforce any religious observance. Bloom v. Richards, 2 Ohio St. 387 (1853); cf. VNN LOON, TOLERANCE (1925).

Compare Iraryland's so-called Act or Edict of Toleration, the Act of Religion of 1649. Its first section prescribed death for those who shall deny the divinity of Jesus and the Hols Family. The only "toleration" was protection guaranteed Protestant Christians by Catholics and vice versa for a ferv. years in order to avoid friction in the Colony. Bancroit and others misconstrued this to constitute 3 highly meritorious, vell-conducted scheme like that of Roger Williams. In fact at no time during the history of the Colony was there toleration for any except Trinitarian Christians, with misery for non-conformists, and no cessation from religious strife. These laws especially persecuted Catholics, all of whom were expressly disfranchised, including Charles Carroll of Carrolton, Marylond's principal signer of the Declaration of Independence. So confused is the public as to the true import of this false "Toleration" even to this day that this Edict of Toleration was adopted as part of the Democratic Platform in Mraryland in 1896. 
minorities, ${ }^{4}$ by providing equal rights and religious freedom for all, it succeeded merely in giving all Christian sects equal rights before the law. Rights have consistently been denied other religious minorities. This is not merely a legal proposition; for in fact an invidious deference is being paid by the state to the miscalled "national religion" of the majority, beyond a mere recognition thereof, a deference that entails, every day, actual proscriptions and hardships in certain states to non-conformists and unbelievers alike, all under color of law. Typical of this inequality was the disallowing and discrediting of testimony of unbelievers in the recent Gastonia trials in North Carolina. 5

The purpose of the present discussion is to show how religious beliefs of the dominant Christians in the United States are allowed effectually to control our every day affairs, not in moot questions or exotic dead-letter blue-laws, but through laws that are actually in force, ${ }^{8}$ or, if not enforced, still dangerous to civil rights of citizens because enforceable at will. ${ }^{7}$

\section{CHRISTIANITY PART OF OUR LAW}

Actual deference is accorded federally, and in the states generally, to Christianity as: (1) a religious belief, in manner offensive to opposing creedists and non-believers; (2) a Church established for such believers, in some states; and (3) a Church supported by militantly evangelical laws, in a few states. Religious hatred has been engendered by this deference to the Church, resulting in such movements as the Inow Nothing

1. "Probably the best test of true liberty in any country is the way in which minorities are treated in that country. Not only should there be complete liberty in matters of religion and opinion; but complete liberty for each man to lead his life as he desires, provided that in so doing ho does not wrong his neighbor." ROOSEvelt, AFricaN AND EUROPEAN ADDRESSES (1910) 69 .

5 These took place at Gastonia and Charlotte, N. C., in September, 1029, in connection with the riots of textile workers at local mills.

- Thus when the Maryland legislature of 1927 appointed a commission to recommend abolition of "obsolete" laws, not one of the state laws herein mentioned as operative was considered in its report.

7 "Interference with differing religious views is not a function of government, nor is it the province of a legislature to determine what roljgion is true or what false. Our government is a civil not a religious institution. Every person has the right to choose his own religion and onjoy it freely, without molestation, apart from religious sentiment, alike entitled to protection so long as be does not invade the rights of others. The legislature is not a proper tribunal to determine what are the laws of. God, for this would involve a legislative decision of a religious controversy." Braterewex, American State Papers Bearing on Sunday Legrstation (Religious Liberty Association Pamphlet). 
Party, the American Protective Association, and Iru-Kluxism, and in the present day participation of the Church in state affairs, through organizations like the Lord's Day Alliance and the Anti-Saloon League, as in the Protestant Chur'ch's part in the late presidential campaign against Governor Smith based on his religion.

When Chancellor Kent of New York said, "The people of this state in common with the people of this country, profess the general doctrine of Christianity as a rule of their faith and practice," 10 he meant "in due form of law," as it had been generally understood under Lord Coke's dictum that "Christianity is part and parcel of the Common Law," $1 x$ and not merely in recognition of the palpable fact that the majority were Christians whose practices must be respected. For in this decision the learned judge set down his dictum that those of exotic beliefs were "impostors" (mentioning the MIoslems, then having more votaries in the world than Christianity), and that such infidels had no rights before a court in a Christian land which Americans were bound to respect.2 Worse than all, this opinion is a key

8 See 5 VoN Holst, Constitutionat Historx (1885) 79 et seq. In the history of the Know-Nothing Party there appears much interference of Catholic prelates in public afrairs, as in the visit of the Papal legate, Cardinal Bedini.

$A$ case may even be made out of recognition of Ku-Klusism in the laws of some states. Cf. Jaurez v. State, 102 Tex. Crim. App. 297 (1925), where county officers sought by law to prevent Catholics from serving as grand jurors. See Seagle, A Christian Country, in American IFercary, Oct. 1925.

10 People v. Ruggles, 8 Johns. 291 (N. Y. 1811).

II Sée Note ANN. CAS. 1913E 1222, 1227; Note (1894). 22 I. R. A. 501 et seg. The following are judicial authority for the proposition that Christianity is part of the common law in the United States: Shover $\nabla$. State, 10 Ark. 259 (1850); State v. Chandler, 2 Har. 553 (Del. 1837); State v. Bott, 31 La. Ann. 663 (1879); Pearce v. Atwood, 13 Ilass. 32\& (1816); Lindenmuller v. People, 33 Barb. 548 (N. Y. 1861); Updegraph v. Comm., 11 S. \& R. 394 (Pa. 1882); Charleston v. Benjamin, 2 Strob, 508 (S. G. 1846) ; Bell v. State, 1 Swan 42 (Tenn. 1851); Grimes v. Harmon, 35 Ind. 198 (1871); IIelvin v. Easley, 52 N. C. 356 (1860); Judefind v. State, 78 IId. 510, 28 Atl. 405 (1894).

12 Under the common law, Jews and Irohammedans were classed with infidels unworthy of belief on oath because the Old Testament did not show a belief in a future world, a doctrine thought to have been introduced by the New Testament of the Christians. In differentiating atheists, skeptics, and non-believers, one must bear in mind the large numbers of confessing members of other faiths than Christianity in this country.

The unequal standing of the so-called "false religions" before the lat is well illustrated in the attitude of the government expressed by the Census Burean. In 1916, a religious census was taken; and this was followed in 1926 by a more elaborate and expensive one published in 1928 listing 213 religious bodies, all Christian except only two, Jews and Bahaists. Yet it is well known that there are many Buddhists, 3roham- 
note, often cited to this day by appellate courts, in deciding re. ligious controversies. There is thus imposed on religious minorities a subserviency insulting to their patriotism.

Following a unanimous opinion of the Supreme Court in Church of Holy Trinity v. United States in 1892,13 Mr. Justice Brewer, in the Haverford Lectures in 1904, showed with ample citations and authorities that this is in fact a "Christian nation." " $\mathrm{He}$ approved the opinion of Mr. Justice Story in the Girard College case ${ }^{15}$ as to Christianity: "Its divine origin and truth are admitted," and for that reason, "Christianity must be neither impugned' nor repudiated."

Lord Coke's dictum, now disposed of as mere rhetoric and not law, has been recognized in many decisions of our courts, ${ }^{20}$

medans, Hindus and others confessing Asiastic religions in this country, some with pretentious houses of worship. That the numbers are negligiblo is not correct, and that small church memberships were not considered is also not correct, because the "summary of more important statistics" as released by the Census Bureau in September, 1928, lists forty-five negligible Christian denominations, each with less than a thousand members and some with less than fifty. The following figures for religions in North America are more significant: Mohammedans, 20,000; Buddhists, 180,000; Hindus, 150,000; Jews, 4,000,000; Confucionists and Troists, 600,000; Shintoists (blank) and Animists, 50,000. Worid Alrianac (1930) 443.

13143 U. S. 457,12 Sup. Ct. 511 (1892) (opinion of Brewer, J.)

14 Brewer, The Unitem States a. Caristian Nation (1905). See especially p. 34, regarding the chaplains of the Army and Navy: until recently exclusively and now generally "their whole range of service whether in prayer or preaching has been an official recognition of Christianity." Cf. also Stephens, School, Church and State (1928) 12 MARQ. L. REv. 206: "Christianity and democracy are not separable if democracy is to persist."

${ }_{15}$ Vidal v. Girard's Executors, 2 How. 127, 199 (U. S. 1844). Christianity was declared to be part of the common law of Pennsylvania. Cf. also ibid. 198: in the case "of a devise in Pennsylvania for the establishment of a school or college for the propagation of Judaism, or Deism, or any other form of infidelity . . . there must be plain, positive, and express provisions, demonstrating not only that Christianity is not to be taught; but that it is to be impugned or repudiated" (as occurs in every Jowish school). Accord: Zeisweiss v. James, 63 Pa. 471 (1870) (declared void a devise for atheistic teaching because an insult to Christianity). But in Manners v. Library Co., 93 Pa. 165 (1880), a bequest for atheistic teaching was sustained.

The former case approved the statement that: "Although Christianity is part of the Common Law of the State, yet it is so in this qualiffed sense, that its divine origin and truth are admitted and therefore it is not to be maliciously and openly reviled and blasphemed against, to the annoyance of believers or the injury of the public." Vidal v. Girard's Executors, supra at 198. See also 3 STORY, CONSTITUTION OF THE UNITED STATES (5th ed. 1891) 628: "It is impossible for those who believe in the truth of Christianity as a divine revelation to doubt that it is the especial duty of government to foster and encourage it among all the citizens and subjects."

10 Supra note 11. 
nicely discriminated in some few states, repudiated in others, ${ }^{12}$ but in several states pressed to its logical conclusion. Thus in Maryland to this very day, according to its highest Court of Appeal:

"The Sabbath is emphatically the day of rest and the day of rest here is the Lord's Day or the Christian Sunday. . . . Ours is a Christian community, and the day set apart as the day of rest is the day consecrated by the resurrection of our Saviour. ... And if the Christian religion is benefited and fostered by this day of rest, as it undoubtedly is, there is all the more reason for enforcement of laws that help to preserve it." ${ }^{28}$

In some states constitutional provisions and statute and benchmade law call for the observance of Christian doctrine and dogma by its citizens. In so doing they deny citizens their inalienable rights and "exclude in whole or part, certain persons not belonging to such adopted religion from participating in public honors, trusts, emoluments, privileges and immunities." 10 Religious proscriptions are found in the following:

Test of witnesses, being belief in a Supreme Being who avenges wrong doing.

Religious test for jurors.

Test of office, being an oath on the faith of a Christian.

Marriage in the face of the church, as a condition precedent to validity.

Blasphemy of the Saviour and Holy Trinity.

At times religious proscriptions amounting to persecution by our courts have been reported in the press, notably of Seventh Day Adventists and Seventh Day Baptists in 1893-1894 in IIaryland, ${ }^{20}$ and again in Tennessee, Arkansas and Kansas.

Iv Bloom v. Richards, supro, note 3. But cf. Board of Fducation v. Minor, 23 Ohio St. 211 (1872), which holds that the Ohio constitution does not enjoin Bible reading in the schools.

18 Judefind v. State, supra note 11, at 516, 28 AtI. at 407; of. Hiller v. State, 124 MId. 385, 92 Atl. 842 (1914); Levering v. Park Commission, 134 MId. 48, 106 Atl. 176 (1919); Spann v. Gaither, 152 IId. 1, 136 Atl. 41 (1927).

Gov. Ritchie now construes the Sunday law to allow athletic performances in state armories despite the protests of the Lord's Day Alliance. See Baltimore Sun, Dec. 13, 1929.

It may be objected that much space is given to Mirargland throughout this article, but it is typical of the backward states, and is the situation with which the writer is best acquainted. Recent indications of the situation in MIaryland are the refusal on November 29, 1929, by Judge Peter at Rockville, MId. of the testimong of an atheist, causing a non pros. in a criminal action, and the protest on January 1, 1930, of Rabbi Israel before the Baltimore School Board against the Christmas exercises held in public school attended by Jews, in which a Catholic priest officiated in his robes. 19 See STORY, op. cit. supra note 15, at 629.

${ }^{20}$ See Aararican Sentinel of Washungton (1895). There was a con- 
And to cap the climax, Christianity is being militantly forced as a creed in several states which require, under penalty, observance of the "Lord's Day" not as a rest day but religiously, and reading and teaching of the New Testament in public schools. ${ }^{21}$ The following sectarian practices, moreover, are uniformly used by both federal and state authorities:

"Year of our Lord," as used in official documents and attestations, particularizes the calendar of the Christians.22

Legislatures all open with prayers addressed to the God of Christianity.23.

Sunday laws call for no work thereon by government officers and employees.

Good Friday and Christmas are Church days set apart as legal holidays.

The days within which a veto must be expressed under the Federal Constitution and those of nearly all states are limited by the phrase, "Sundays excepted."

Considering the fact that the history of America's colonies shows that they were established to further Christianity, it is not remarkable that the newly constituted states began to establish Christianity during and immediately after the Revolutionary War. In all the state constitutions there is mention of God, but in none of them is there mention of Christ or the Holy Trinity, ${ }^{24}$ although there are mentions of Christianity and the duty to worship God. Yet it may be argued with Mr. Justice Brewer that, because of religious references in certain of these constitutions, especially to Christian beliefs and dogmas, and likewise in deci-

certed persecution in 1893, especially near Ford's Store, Md., culminating on the one hand in the Judefind case, supra note 11, and on the other in the sending to jail of a Seventh Day Adrentist because he refused to testify on his holy day, the seventh day Sabbath.

21 To this list might be added the celebration in public schools of Christmas and Easter as religious occasions for evangelical purposes, the compulsory attendance of dissenters in the public schools and prevention of their attendance inl parochial schools, and finally the prohibition of the teaching of evolution in schools.

22 To Moslems and especially to the believing Jew, the use of these words is heresy in violent conflict with his confession of faith. For such refusal to express belief in the divinity of Christ, tens of thousands of Jews have suffered martyrdom these 1800 years, and continue to be proscribed, ostracized, and otherwise to suffer socially everywhere to this day. Compare the persecution of Doctor Lumbrozo, infra note 85 .

23 In order not to offend the sensibilities of mixed assemblies, however, it is now usual to have prayers addressed to the Deity in' general, like "Our Heavenly Father," and to exclude all reference to Christ.

21 But in no charter or constitution is there mention of any other creed than Christianity. See BRETEER, op. cit. supra note 14, at 27. 
sions of appellate courts, that reference is thereby made to the God of the Christians.

By the constitution of South Carolina of 1778, "the Christian Protestant religion was constituted and declared to be the established religion of the State." 25 Under the constitution of MTaryland of 1776, the legislature may in its own discretion lay a general and equal tax for the support of the Christian religion. The constitution of Massachusetts of 1780 was mandatory, requiring municipalities to make provision for the public worship of God and the support of Protestant teachers of religion. In Vermont's constitutions of 1793 and 1813 every denomination of Christians "ought to observe the Lord's Day and keep up some hind of religious worship." By New Jersey's constitution of 1776, no Protestant inhabitant shall be denied the enjoyment of his civil rights. Both Connecticut (1818) and New Hampshire (1912) not only state that every denomination of Christians shall be equally under the protection of the law, but New Hampshire allows municipalities to levy a tax to support Protestant Christian schools, ${ }^{20}$ and Connecticut prescribes rules for Christian church membership. The Mlississippi constitition prescribes that the Holy Bible must not be excluded from the public schools.27 More liberally the constitutions of Nebraska and Ohio prescribe that laws shall be passed to protect every kind of religious worship. These religious discriminations are in a different category from the generalization of Virginia's constitution of 1902, where it is stated that the moral duty of all is to practice Christian forbearance, love and charity-following Thomas Jefferson, who disbelieved in New Testament miracles but published the morals of Christ.

Despite the general impression to the contrary, the First Amendment to the Federal Constitution did not for all time fix religious freedom in America; it merely denied to Congress the right to establish religious worship, reserving this power to the states. ${ }^{28}$ And religious liberty in several of the states has progressed no further than this definition: All persons professing the Christian religion are equally entitled to the protection of their religious liberty.9 Indeed, equality of all Christians be-

\footnotetext{
25 See for this and the subsequent constitutional provisions, IETTLEBOROUGH, IIANUAT OF STATE CoNSTITUTIONS (1918).

${ }^{26}$ Cf. Hale v. Everett, 53 N. H. 9 (1868).

${ }_{27} \mathrm{Cf}_{\text {. Hackett }}$. Brooksville, $120 \mathrm{Ky} .608,87$ S. W. 792 (1905), where a similar result is reached by judicial decision. Here the prayer authorized was: "These things we ask for Christ's sake."

28 Permoli v. NTew Orleans, 3 How. 589, 609 (U. S. 1845). See U. S. C. A. Const. Pt. 2, p. 454 (1926), for full list of cases.

${ }^{28} \mathrm{Cf}$. the constitutions of Connecticut, Massachusetts, and New Hampshire. See also the view of Judge Samuel Chase, later Chief Justice of the United States, in Runkel 7 . Winemiller, 4 H. \& IICH. 429, 450 (MId.
} 
fore the law was the highest ideal of the colonists, and it has continued so, even in those words, to this day. The result is an institution here similar to the established Church of England, which has been defined as follows: "It is established by law, in that the State recognizes it as the National Church of the English people, an integral part of the Constitution of the realm." so

In contrast, one is reminded at this point of the present day rights before the law in England for all nonconformists, believers and non-believers alike, and of the deference paid to all of them. Thus, the state feels bound to admit them all to, office, to receive their oaths and affidavits, to accept their testimony, to give them equal rights to marry without reference to a creed or no creed, to purge their expressions of disbelief in Christ of the charge of blasphemy, and so on. The House of Lords in Fngland has definitely thrown out the ruling that Christianity is part and parcel of the common law in Bowman v. Secular Society ${ }^{32}$ and Bourne v. Keane. ${ }^{32}$ Singularly these decisions of a decade ago had not until recently been brought to the attention of lawyers, either in opinions, or in text books or law publications, and even now are not generally lmown. And the mischief lies in the capital made out of the statement by. Colre, as reinforced by, Chancellor Kent for America, establishing precedents here which it will be hard to uproot, and a body of substantial law difficult to set aside, and worst of all, a public opinion not to be changed at all, if the present zeal of bigots is to measure it.

\section{ARE OATHS OF BELIEVERS ALONE BELIEVABLE?}

The world has been so long habituated to giving credence to affidavits founded on religious beliefs, that the expression, by such an oath, of belief in a Supreme Being who will hold one to account either in this world or in the world to come for false swearing seems even today to most men the one reliable means of undertaking an obligation to tell the truth. This is the common law except where changed by statute. ${ }^{33}$

Is a man's credibility to be rated according to his connection

1799): "All sects and denominations of Christians are placed upon tho same equal footing, and are equally entitled to protection in their religious liberty."

309 ENCL. BRIT. (11th ed. 1910) 442. A nice differentiation appears in Lindenmuller v. People, supra note 11, at 561: "Christianity is not the legal religion of the State as established by law. If it were it would bo a civil or political institution, which it is not."

$31 .[1917]$ A. C. 406.

32 [1919] A. C. 815. Both these cases were ably discussed in their relation to the American situation by Max J. Kobler of the Now York bar in (1928) 31 ADr. JEWISH HIST. Soc. 105.

${ }^{33}$ Cf. Jackson v. Gridley, 18 Johns, 98 (N: Y. 1820). 
with a religious organization or belief in its tenets? There are many intelligent men today who could not conscientiously take an oath on the Gospels, or with reference to God. ${ }^{34}$ If challenged upon the test of belief in a future state of reward and punishments in this world or elsewhere under God's dispensation, they would fail. There are many high class lawyers of the type of Clarence Darrow who must be disqualified, if put to the test; likewise many good churchmen, who call themselves IIodernists.

The State is interested in the truth-telling of witnesses, not in their religious beliefs. It does everything to make the obligation to tell the whole truth solemn and impressive, binding on the conscience of the affiant, with the caution that perjury will be met by punishment as an offense against the peace, order, and dignity of the State and not against a Supreme Being. The fervor of the colonists' religious devotion simply reflected the ancient common law view that non-conformists and non-believers in the God of the Established Church were non digmus fide, not worthy of belief. Lord Coke's mischievous doctrine that such unbelievers were perpetui inimici, eternal enemies, was only partially relieved by a later decision, for the one practical purpose of letting in the testimony of Jews and Eastern non-believers as to the contracts of Englishmen, according to the custom of merchants. ${ }^{35}$

Thus it was at the beginning of Statehood, and has continued in some states to this day. Significantly it was the rule of evidence for all federal courts by the Judiciary Act of 1789 , so that by federal law a witness was not competent to testify who did "not believe that there is a God who rewards truth and avenges falsehood.". The rule was amended by Act of Congress, June $29,1906,{ }^{33}$ providing that the competency of a witness to testify in any civil action, suit, or proceeding in the courts of the United States is to be determined by the laws of the state in which the court is held. But this, as we shall see, works an injustice to

34 When Robert C. Ingersoll, an agnostic, became Attorney General of Illinois in 1868, non-believers were disqualified as witnesses under Central IIilitary R. R. v. Rockafellow, 17 Il. 541 (1856). Out of respect for him the constitution of the state was amended in 1870 sa as to change the rule.

35 Omichund v. Barker, Will. 538 (1744). See Calvin's Case, T Co. Rep. 1, 1a (1608); 2 HATE, PIEAS OF THE Crown (1778)' 279. From the time of their expulsion in 1290 until Cromwell's protectorate, Jews had no legal right to be in England, but they were there in large numbers, being useful in trade with Spain and outlying countries. When their testimony was required to confirm such contracts, it appears that the courts received it. At the same time they admitted the testimong of Indian infidels, believers in a God who avenges wrong-doing.

36 34 STAT. 618 (1906), 28 U. S. C. § 631 (1926); see ROSE, FEDEERT JURISDICTION (3d ed. 1926) § 523. 
the non-believer and non-conformist in some states. ${ }^{37}$ It is a later development, not yet reached in all states, that there are non-believers, even atheists, whose word can be believed, even though they cannot measure up to the formal requirements of the old common law rule.

Since Omichund v. Barker ${ }^{38}$ reversed the mischievous dictum of Lord Colke, there has grown up in England and America a body of public opinion reflected in legal decisions that the oaths of unbelievers deserve respect. So that in England, even with an Established Church, and in the liberal states of the Union no person is "incapacitated from being a witness on account of his religious belief" (overruling Chancellor Kent), and any form of oath suffices that actually binds the particular witness's conscience even if it varies from the orthodox form. ${ }^{39}$ But the old rule has not yet completely relaxed its hold in America and requires obeisance in certain reactionary states. A typical provision is the following clause in the Bill of Rights of the Mary. land Constitution:

"Nor shall any person, otherwise competent, be deemed incompetent as a witness or a juror, on account of his religious belief; provided he believes in the existence of God and that under His dispensation, such person will be held morally accountable for his acts and be rewarded or punished therefor in this world or the world to come." 40

In Virginia a witness who believes in a Supreme Being and present punishment was held in the early leading case of Perry v. Commonwealth ${ }^{41}$ to be competent because no religious opinion was there required by statute; likewise in Kentucky and other

${ }^{37}$ A moot case has been suggested by Charles G. Baldwin as to the incompetence of witnesses, because of lack of belief in a Supreme Being who avenges wrong-doing, to make affidavits for the following purposes: to become a registered voter, to take out a patent, to become naturalized as a citizen, to obtain a passport, to be a candidate in a primary, to onlist in the army, navy, or militia, to file income tax returns, etc. Seo Tho Baltimore Daily Record, Feb. 4, 1930. But these are privileged under tho federal rules, and they are referable to state law only where as indicated supra note 36 , the federal officer is bound to enforce the state disqualification.

38 Supra note 35.

30 State v. Jackson, 156 Iowa 588, 137 N. W. 1034 (1912).

to MAARYLAND CoNSTITUTION (1867) art. 36. This was construed against disbelievers in State v. Mercer, 101 Md. 535, 61. Atl. 220 (1905). In order to accommodate the Universalists the belief as to punishment in a future world was abandoned in favor of belief in punishment inflicted by God in this life. But an old Connecticut case held otherwise. Atwood v. Welton, 7 Conn. 66, 74 (1828) (citing Mr. Justice Story and Curtiss v. Strong, infra note 52).

413 Gratt. 632 (Va. 1846).

22 Bush v. Comm., 80 Ky. 244 (1882). 
states. In New Jersey the same rule applies to all cases in which the witness is a party to the proceedings.13 Despite North Carolina's liberal constitution, Shaw $v$. Moore semains the law of the state requiring belief in God and divine punishment as the test of competency of witnesses. In that case one was admitted who believed "in the obligation of an oath on the Bible, in God and Jesus Christ, and that God will punish in this world all violations of His law, that the sinner will be inevitably punished in this world for each and every sin, but there would be no punishment after death, but all would be happy and equal to angels." ss In Delaware, a disbeliever has been held to be incompetent because the constitution impliedly requires belief in a Deity. ${ }^{48}$ On the other hand Connecticut by its late Constitution of 1888 reverses its former disqualification of atheists and now admits their evidence; the like has happened in New York, Kansas, and Florida.

There are several constitutions which are verJ liberal, and. likewise many judicial constructions quite contrany to the above restrictions. For example, in Arizona the mode of administering an oath or affirmation must be such as shall be most consistent with and binding upon the conscience of the person making such oath or affirmation.

Typical of the modernlview, also, is the decision in a Louisiana criminal case that an atheist may testify, since the statute does not make belief in the existence of a God essential.s Such a decision Ieads to the doctrine laid down for English law that "a witness may be sworn in the form which he expressly or impliedly declares to be binding on his conscience"-a doctrine founded on the liberal English statute which is in nearly the same words. 48

Generally speaking there continues to be a great advance in many states to set aside the religious disqualification, but much

43 Percey v. Powers, 51 N. J. I. 432, 17 Atl. 969 (1889).

44 N. C. 25 . (1856).

15 Ibid. In the course of the opinion in Perry's case, supra note 41, at 643, Judge Scott said: "The enforcement of the high test contended for, of a belief in future rewards and punishments, might present the spectacle of a. Christian man found guilty by an Infidel jury sentenced by an unbelieving Judge, and denied mercy by an Atheist Governor; and all because of the rejection of a Christian vitness; for all Christians do not believe in future punishments."

16 Perry v. Stewart, 2 Har 37 (Del. 1835).

47 State v. Williams, 111 La. 179, 35 So. 505 (1903).

181 \& 2 Vicr. c. 105, Iater reproduced in the British Oaths Act of 1888, 51 \& 52 VICT. c. 46, as follows: "Every person upon objecting to being sworn and stating as the ground of such objection that he hes no religious belief, or that the taking of an oath is contrary to his religious belief, shall be permitted to make his solemn affirmation instead of taking an oath." 
confusion remains in judicial opinions. Even under federal procedure the testimony of Chinamen for certain purposes is held unreliable and must be corroborated by that of white men, on the ground of lack of proper religious beliefs. ${ }^{40}$

The evidence of a witness who did not regard the obligation of an oath as higher than that of her word has been rejected in England, and this rule is now generally followed in this country. ${ }^{50}$ Clearly a witness must be sensible of the obligation of an oath, before he can be permitted to testify, and under any condition is punishable criminally for false sweaxing. The law requires either of two guaranties of the truth of what a witness is about to state, not necessarily both; he must be in fear of punishment by the laws of man, or he must be in fear of punishment by the laws of God. ${ }^{51}$

Now consider the qualification of witnesses to formal papers. Many affidavits and attestations to such formal papers as complaints, bills in equity, proofs of claims, deeds of trust, and wills, which constitute the only proof of thousands of juridical facts arising daily in our modern life, are likely to be thrown out because the oath may be challenged for religious disqualification. A leading case is Curtiss v. Strong, ${ }^{52}$ where under the traditional religious disqualification, one who did not believe in the obligation of an oath or any accountability for his conduct after death was held not to be a competent witness to a will, and the will was consequently not admitted to probate. A later Pennsylvania case decided that even after the death of an attesting witness, a non-believer, his competency could be attacked and the will impeached.53 Under similar authority in the states which disqualify unbelieving witnesses, it is inevitable that rights in property will be assailed now that this opening to attack is made, with results most unexpected by the parties in interest. Confronted with these authorities, prudent lawyers in states where testimony of such non-believers will not be received will meticulously select believers as attesting witnesses to all documents, in order to avoid the risk of a fatal disqualification.

$49 \mathrm{Li}$ Sing v. United States, 180 U. S. 486, 21 Sup. Ct. 449 (1900).

50 Maden v. Catanach, 7 H. \& N. 360 (1861); of. Lee v. Missouri R. R., 67 Kan. 402, 73 Pac. 110 (1903); Hayden v. Hayden, 107 Neb. 806, 186 N. W. 972 (1922).

5 For citations and a full summary of the religious disqualifications in the different states, see Notes (1898) 42 L. R. A. 568; (1909) 23 L. R. A. (N. S.) 1023. See also 28 R. C. L. § 41 . The burden-of proof of a roligious disqualification is on the objecting party. Arnd v. Amling, $53 \mathrm{Md}$. 192 (1879); DuPuy v. Terminal, 82 ikd. 443, 34 Atl. 462 (1806).

524 Day 51 (Conn. 1809). This case was overruled due to a constitutional change in Ruocco v. Logiocco, 104 Conn. 585, 134 Atl. 73 (1026). Cf. State v. Mercer, supra note $400^{\circ}$

${ }_{53}$ Harding v. Harding, $18 \mathrm{~Pa} .340$ (1852). 
The right to give testimony is not merely a privilege, but is an especially valuable right to a citizen, if he be a party in interest or wish to testify for sentimental or business reasons. Moreover according to decisions in New Jersey and Illinois, ;s it is a property right, guaranteed under the Fourteen Amendment to the Constitution. Other states will surely follow the New Jersey statute which recognizes the inalienable right of a party in interest, whatever his beliefs, to give his testimony. ${ }^{\circ 5}$

Under much the same line of law and precedent, disqualification of jurors has resulted in states having antiquated laws and restrictions. Maryland, leading this line of attack, has decided that an indictment must fail where a member of the grand jury which found it was disqualified for non-belief.:

\section{OFFICIAL OATHS FOUNDED ON CERISTIAN BELIEE}

Despite the sixth article of the Gonstitution of the United States that no religious test shall ever be required as a qualification to any office or public trust under the United States, this has not been taken seriously by the states, even by those whose constitutions "made this Constitution and laws made or which shall be made in pursuance thereof" paramount." Thus until $1877 \mathrm{New}$ Hampshire required that its state Senators and Representatives should be of the Protestant religion."s Like restrictive words had been formerly used in the constitutions of Delaware, South Carolina, IIassachusetts, Connecticut and Vermont.s In many states the oath of office ends in the words "So Help IIT God," which formula has been interpreted to require a belief in a God to whom one is answerable for his sins. ${ }^{\circ 0}$ The Arkansas

5s Percey v. Powers, supra note 43; Hronek v. People, 134 IIl. 139, 24 N. F. 861 (1890).

55 Supra note 43; of. Brink v. Stratton, 176 N. Y. 150, 68 N. E. 148 (1903) (denying the right even to question such witness).

so State $\nabla$. ITercer, suprai note 40.

57 MIARYIAND GONSTITUTION (1867) Declaration of Rights, art. 2.

o Neiv HanipshIRe Constitution (1877) pt. 2, art. 14.

so DeLaWfare Constitution (1776). Ivery officeholder was required to subscribe to the following: "I, A.B., do profess faith in God the Father; and in Jesus Christ, his Only Son, and in the Holy Ghost, one God, blessed forevermore; and I do acknowledge the Holy Scriptures of the Old and New Testament, to be given by divine inspiration." The Constitution of 1818 changed this.

See for full citations KeTrLEBorodGH, supra note 25.

¿o Alabama, Connecticut, Florida, Louisiana, Iraine, Mrassachusetts, Mrississippi, New Hampshire, Rhode Island, Vermont, and Virginia. Seo KeTrLeBorodgh, supra note 25.

The words "So Held IIJe God" have for thirty years been taken out of the judicial oath in Ifargland by statute and the method of administering it restricted to uplifting the hand-unless some other mode of administer- 
constitution prescribes that: "No person who denies the being of a God shall hold any office in the civil departments of the state or be competent to testify as a witness in any Court." ar In North Carolina, "all persons who shall deny the being of Almighty God are disqualified from office." 02 Under Pennsylvania's present constitution, "no person who acknowledges the being of a God or a future state of rewards and punishments shall on account of his religious opinions be so disqualified." os It would seem that disqualification for public office follows as an inference from these words.

In Maryland until the constitution of 1851 all office-holding depended upon a declaration of a belief in the Christian religion. Jews, however, had been exempted since 1826. Its present constitution prescribes that there shall be no test "other than a declaration of belief in the existence of God." os In spite of this, the Code of Public General Laws (1924) prescribes for the oath of office a declaration of belief in the Christian religion, ${ }^{\circ 5}$ as had been the case before the constitution of 1851. Under the earlier rule, no Jew could qualify for even the smallest office, nor practice law. In 1826, following a conflict beginning in 1797 , an exemption was granted to Jews who would declare themselves such and "express belief in a future state of rewards and punishments." This exemption is continued in the present law. ${ }^{6 B}$ All others are excluded from office, non-conforming Christians, believers in so-called false religions, non-believers, and atheists. Yet Maryland's "Bill of Rights" provides that no man is to be molested in his religious profession or practice

ing the oath is "more binding on the conscience of the swearer." In practice, kissing the Bible and using "So Help Me God" is usual,

61 Arkansas Constitution (1874) art. 19, § 1. Cf. Mueller v. Coffman, 132 Ark. 45, 200 S. W. 136 (1918). Tennessee has almost the same words except as to competency of witnesses. TenNesser Construturion' (1910) art. 9.

b2 Norte Carolina Constitution (1868) art. 6, § 8.

63 Pennsyluanta Constimution (1873) $\S \S 1-4$.

es MRARYLAand Constitumion (1867). Declaration of Rights, art. 37. This phrase was protested by a high churchman, Bernard Carter, in the constitutional assembly of 1867. For the history of this debate, see Davidson v. Brice, 91 Md. 681, 688, 48 Atl. 52, 53 (1900).

65 MD. ANN. CODE (Bagby, 1924) art. 70, \& 9, apparently violating the constitutional provision: "Nor, shall the legislature prescribe any other oath of office than the oath prescribed by this Constitution." Supra note 64 .

60 Supra note 65. See Axtrald, The Jetrish Strugate for Rintrarous AND CrvIC IIBERTY IN MARYLAND (1924). Chief Justice Marshall must have known of this struggle, yet in 1819 he uttered the dangerous dictum that the legislature may superadd to the oath directed by the Constitution such other oath of office as its wisdom may suggest. See McCulloch v. Maryland, 4 Wheat. 316, 416 (U. S. 1819). 
unless he "disturbs the good order, peace and safety of the State or shall infringe the laws of morality or injure others in their natural civil or religious rights."

\section{COMPELLING IIARRIAGE IN THE FACE OF THE CHURCH}

Church domination so far as it interferes with the right to marry has been removed everywhere in the United States except in Maryland and West Virginia, where alone religious sanctification of every lawful marriage is both by statute and decision unqualifiedly and unconditionally required. Common law marriages, by contract per verba de praessnti, are not everywhere allowed, and of course not in these two states. But most states by constitution, statute, and decisions have gone to the length of providing that when parties to a marriage have procured a religious officer to sanctify a religious ceremony for them, believing him duly authorized, and they have cohabited, they are considered fully married even if he lacked authority. Code provisions and decisions everywhere now confirm this.or ITaryland again was very backward, and not until 1925 in Knapp $v$. Irnapp ${ }^{68}$ did it announce its adhesion to this palpably just maxim of law. Before the amendment of June, 1927, MTaryland law penalized those who had left the state to be married because they did not wish to have their marriage sanctified religiously or by a minister whose authority was doubtful or offensive. And until 1927 the right to perform marriage vested exclusively in Quakers and in Ministers of the Gospel.09 In Utah the solemnizer must be a priest, but it is open to question whether this means a priest of the Mormon Church..$^{\circ}$ In Rhode Island, Jews may intermarry uncle with niece, a Talmudic privilege denied elsewhere. ${ }^{71}$ The authority of the marrying minister is often expressed in the statutes of the states in words of doubtful meaning requiring judicial interpretation. This authority should everywhere be expressly made unequivocal by bestowing rights on all religious organizations alike, with the right of a civil marriage to those who wish it.

ot E.g., GeN. LaWS MaSS. (1921) c. 204, \$ 42.

68149 IId. 217, 131 Atl. 329 (1925). This decision came in time to save an awhward situation. In 1929 at Ellton, ifaryland, long lnown as the Gretna Green or Miarriage IIill for the nearby states of Pennsylvanis, Delaware and New Jersey, because of placing no restrictions of residence or notice, an advertising marrying parson was convicted of performing marriages when not authorized to do so by his religious organization. The five hundred couples thus married illegally vere pronounced "Iegally redded," under the Knapp decision.

$69 \mathrm{ITD}$. ANN. CODE (Bagby, 1924) art. 62, §4.

70 UTAH LATS (1917) § 2971.

7R. I. GEN. IAWS (1923) c. $287, \S 4$. 
The Russell Sage Foundation has rendered a great public service by placing a manual of the laws of mamiage and divorce, carefully prepared and documented, within the reach of all.72 And because of this publication of comparative legislation, there. is likely to be further emancipation in this direction.

\section{SUNDAY LAWS}

It has been said that the common law tolerance of Sunday la-. bor was changed for England (and of course its colonies) by the Act of 29 Charles II in $1678 .{ }^{73}$ Maryland's miscalled "Fdict of Toleration" was passed in 1649, eleven years after it was first. proposed by Lord Baltimore for the colonists. It provided fines. and whipping for such as should profane the Sabbath "by any unciville or disorderly recreation or working on that day." 74 The more recent use of the term the "Lord's Day" as a synonym. for Sunday in the Judefind case ${ }^{75}$ sufficiently shows that to such. an extent at least the religious liberty of non-conformists and. non-believers is still infringed upon. There is some progress, due to general agitation, in that the justification of Sunday laws . by appeal to Christianity, even in Maryland, is now modified by: judicial reference to police powers to enforce Sunday rest, and. the religious doctrine is not so hard pressed in later decisions. . Nevertheless, though the Judefind case states that "Sunday laws . are to be given a reasonable constuuction," and that "such Sun.. day laws are not opposed to religious liberty," the sad experience of non-conformists in that state to this day contradicts it. ${ }^{70}$. In.

22 Max, Marriage Laws and Dectsions in the United Sitates (1029).. 7329 CAR. II, c. 7 (1678).

74 MIaryland's "Sabbath Breaking" Law, MD. ANN. CoDE (Bagby, 1924) art. $27, \S 483$, is the very act of 1723 , which in turn was based on the Act of Religion of $1649, \S 4$. See Hartogensis, Whorein Maryland is not a Free State, Debunker, January; 1929.

This nickname "Free State" was recently bestowed upon Maryland by a native son, H. I. Mencken, because of its deliberate unwillingness to . adopt legislative measures concurrently with the Federal Government to. enforce Prohibition under the 18th Amendment; "free" since the abolition . of slavery in 1864; but no more "free" from Church domination than : other states, and less "free" as to religious freedom.

75 Supra note 11.

${ }^{70}$ Ibid. Regularly every Monday the newspapers of Baltimore report arrests with frequent fines for petty violations of the lat. While the . present law still forbids recreation on this day, the executive now construes the act to allow athletic performances in state armories, despite the protests of the Lord's Day Alliance. See Governor Ritchie's ruling in the Baltimore Sun, Dec. 13, 1929. In the Maryland Constitutional Convention of 1867 , an appeal for a statement of religious liberty instead of toleration. in the Declaration of Rights was voted down 47 to 17 . when it was met: with the argument that such an amendment would take away from tho: 
1908 the same Sabbath-breaking act of Maryland, till then the law of the District of Columbia: (by inheritance) was denounced by a federal court as unconstitutional because "designed not as a civil duty but as a religious obligation." $\pi$

Nor is it true that there is no interference with the religious beliefs of the non-orthodox in merely compelling them to observe Sunday as a day of rest; for the Seventh Day Adventists and Baptists and certain orthodox Jews literally constzue the Fourth Commandment of the Decalogue, "Six Days shalt thou labor"; wherefore they must perforce work on Sunday in violation of "Lord's Day" Sabbath-breaking laws. In Virginia and twenty other states, however, regular religious observance of some other day may be pleaded as a defense.

Again, shall the measure of cessation from labor be literally, "Let no man go out of his place on the seventh day," "7o as followed narrowly by some Presbyterians and formerly the Karaite Jews, who demand a day of austerity; or shall it be a day "of delight," " Roman Catholics; or a denial of certain pleasures as by the Iord's Day Alliance? In California and Oregon originally, and now the District of Columbia, there are no Sabbath laws; yet there is general cessation from labor, while disturbance of public worship and of neighborhood quiet are offenses there as elsewhere.

In Soon Hing v. Crowley, Mr. Justice Field laid down the modern theory for the guidance of jurists: "Laws setting aside Sunday as a day of rest, are upheld not from any right of government to Iegislate for the promotion of religious observance, but from its right to protect all persons from the physical and moral debasement, which comes from uninterrupted labor." 80 It is to prevent such social injustice that modern states like California have statutes preventing laboring men from engaging

legislature "all regulation of the Sabbath." PERLMaAN, ILARYunND ConSTITUTIONAL CONVENTION OF 1867 (1923).

72 Dist. of Col. v. Robinson, 30 App. D. G. 283 (1908). In spite of this decision Representative Lankford of Georgia, backed by the Lord's Day Alliance, is trying to force a Sunday Law by Act of Congress on the District of Columbia, in clear violation of the First Amendment to the Federal Constitution.

78 Exop. 16:29.

29 ISAIAH 58:13.

80 113 U. S. 703, 710, 5 Sup. Ct. 730, 734 (1885). Great public service is rendered by the Religious Liberty Association of Washington, D. C., and similar associations as of Seventh Day Adventists. See, in general, Friedenberg, Sunday Laws of the United States and Judicial Decisions Having Special Reference to Jews (191T) AMIERICAN JeITISH YeAr BooK; HoLMIE, AMIERICAN GrvI LIBERTES UNION. 
in more than six days continuous occupation in any one weel, without prescribing any one certain day of rest for all.s1

Vermont explicitly provides for Sunday observance in its constitution.

\section{BLASPHEMY}

The recognized propriety of respect for the God of the Christians in this country. of Christians has naturally called for statutes to prevent the making of such disrespectful reference to the Godhead as would offend true believers. A modern reading of the Third Commandment of the Decalogue, not to take God's name in vain, should lead to the prohibition of offensive reference to the Godhead of any religion, or to any being or thing held sacred, in the hearing of a believer in any such creed or in malicious publications; all this of course, for the sole and only purpose of maintaining the peace and dignity of the state. Yet statutes penalizing blasphemy rest almost entirely on Christianity being part and parcel of the common law.

It must come then as a shock to learn of criminal statutes in the United States-enforceable and sometimes enforcedwherein, to the exclusion of other creeds, the divinity of Christ and the Holy Family are set down as matters of belief, and to utter as to him and them "profane" words (not necessarily offensive words) or to deny such divinity, constitutes a crime. There is no reference whatsoever to belief in or offensive references to other Godheads, or to things held sacred by others than believing Trinitarian Christians. Even the rights of Christians other than believers in the Trinity or the divinity of Christ are here disregarded. This harks back to Blackstone's definition of "blasphemy against the Almighty": "Denying his. being or providence, . . . contumelious reproaches of our Saviour Christ, ... profane scoffing at the Holy Scripture or exposing it to contempt and ridicule." 82

Happily the law elsewhere does not go to such length as in Maryland, which makes it a crime "to blaspheme or curse God or write or utter profane words about our Saviour Jesus Christ or of or concerning the Trinity or any of the persons thereof"; 83 although in Pennsylvania much the same language has been construed to mean the denial of the divinity of Christ.84 This was the interpretation put on the rule in the earliest and the only reported case on blasphemy in Maryland, that of Lumbrozo.

SI GAL. GEN. LAWTS (Deering, 1923) tit. 350, act $\$ 718$.

324 BL. COMM. $* 59$.

83 MDJ ANN. CoDE (Bagby, 1924) art. 27, § 24.

84 Updegraph v. Comm., shepra note 11 . 
The early colonists in ITaryland under Lord Cecil Calvert began to force their religious beliefs on Unitarians, non-believers, and the many Jewish merchants who were then in the colony. The "Edict of Toleration" of 1649 prescribed hanging and confiscation of goods for denial of such divinity, following English precedent. Nine years thereafter they actually made ready to hang a Jew, the distinguished chirurgeon Dr. Lumbrozo, merely because he would not affirm such belief in Christ. ${ }^{85}$ And the greatest surprise of all is that despite frequent castigation for this namowness, the good people of Maryland insist on keeping the statute of 1649 in effect in 1924, in much the same words as the original with the penalty reduced to six months in jail and a fine of $\$ 100.88$

Maine, Massachusetts and other states 'have like mediaeval laws of the Church. Chancellor Kent dealt with their constitutionality in these words: "Shall we say that any word or deed, which would expose the God of the Christian religion or the Holy Scriptures to contempt ridicule, would be protected by a constitutional religious freedom? We register a most emphatic negative." This even though the law in question did not punish lilke attacks on "religious imposters," like "Mahomet and the Grand Ilama." st A leading Massachusetts case, Commonvealtic v. Inneeland, 88 handed down in 1838 and nevel overruled, goes great lengths in claiming superiority for orthodox Christian - belief, with the inevitable suggestion of a union of Church and State. There a conviction of an editor or publisher was sustained because he "maliciously" printed these words: "Universalists believe in a God.which I do not; but I believe their God with all his moral attributes (aside from nature itself) is nothing more than a mere chimera of their own imagination."

In England with Christianity established by law, since 1883, non-conformists and Jews, even an atheist like.Bradlaugh, are allowed their civil rights, and blasphemous libel is something other than the denial of the truth of Christianity, under the law of the land.ss The burden of a proper modern prosecution of blasphemy should be wilfully and with public contumely to ridicule a prevalent religion, not only with offense to the sensibilities of believers, but likewise against the public peace. ${ }^{00}$

85 See AITFELD, op. cit. supra note 66, at 3. It is interesting to note that Iumbrozo subsequently affirmed his faith as a Christian and only then was allowed to enjoy the rights of a denizen, including jury service.

so Supra note 83.

8т See People v. Ruggles, supra note 10.

8820 Pick. 206 (Mass. 1838).

${ }^{82}$ Att'y Gen'I v. Bradlaugh, 14 Q. B. D. 667 (1885).

90 Full notes on this subject appear in (1921) 14 A. I. R. 880, and (1927) 48 A. T. R. 85. 


\section{BIBLE READING IN THE SCHOOLS}

That Christianity is the "national religion" as a matter of $\mathrm{law}_{n}$ except where altered by state constitution or statute, is set forth in a straightforward way by many recent opinions referring to religious teaching and devotional exercises in public schools. II In some cases surprise is expressed that any others than believing Christians are to be considered at all; and in a few cases Jews and non-conformists are deliberately told that they have no legal rights in their religion, and that whatever remedies are given for differences in sectarianism, they refer to doctrinal and dogmatic differences between the various Christian sects only. So it has been held that the constitutions of the several states were not intended to apply to members of other religions in granting freedom from support of the Christian religion by the state; but theyl were more particularly intended to apply to sects of the "common national religion." 02

In connection with sectarianism in the public schools there is arising a great body of law, much of it carefully annotated and reviewed. There is apparent confusion in these conflicting opinions; many are not carefully considered and are written for "local consideration." Many pretend to, but do not, actually follow federál construction and the leadership and modern outlook in other states, nor do many consider opinions expressly 。 overruled; they as often cite obiter dicta as fixed law.

The extremes of bigotry appear in the attempt to have Bible readings in public schools by teachers wearing the garb of nuns, ${ }^{23}$ and again in the compelling of public school children of objecting Catholic parents to attend the reading of a King James Version and an Episcopalian version of the Lord's Prayer at devotional exercises in the public schools. ${ }^{04}$ There was an injection of humor into one of these hate-promoting cases by a Louisiana court, which threw objecting Catholics out, but sustained a verdict in favor of Jews, both of whom had protested the reading of the New Testament in the schools. ${ }^{.5}$ Consider in this connection a decision which allows part of school time to

${ }^{21}$ Cf. State v. Weedman, 226 N. W. 348 (S. D. 1929) (Sherwood, J., dissenting). The more liberal view appears in People v. Board of Iducation, 245 Ill. 334, 92 N. E. 251 (1910); and State v. Sheve, 65 Nob. 853,91 N. W. 846 (1902).

-92 Wilkerson v. City of Rome, $152 \mathrm{Ga}$ 752, 110 S. F. 895 (1922), disapproving of People v. Board of Education, supra note 91.

${ }^{93}$ Knowlton v. Raumbover, 182 Iowa 691,166 N. W. 202 (1918).

94 State v. Weedman, supra note 91. Cf. Stevenson v. Hanyon, 7 Pa. Dist. 585, 590 (1898): "The suggestion that the Bible in either version is a sectarian book borders on sacrilege."

$9^{96}$ Herold v. School Directors, 136 La. 1034, 68 So. 116 (1915). 
be taken by school children for religious instruction outside of the school building.96

It is in religious differences that men's passions sway them most from their usual reasoning, ofttimes with the widest divergence as to the implications of the meaning of common words in general use. To many liberals it seems inexplicable that under the guarantee of "religious freedom" there can possibly be any such deference to one religious organization and to persons avowing faith therein. "Religious freedom" to the liberal means the obligation to assure to all ease of conscience and the fullest right to worship (where such does not conflict with health or public.morals), without priority or privilege to any one. He would even deny, for instance, that Bible reading should be for the purpose of developing either a religious or a Christian character in the pupils, yet this idea is put forth by several courts of last resort. With the present acrimonious discussion of the exclusive title to the word "Christian" going on between various sects, it would be difficult to find an agreement or a judicial finding as to who were embraced in this term. But apart from this, many zealous Christians even insist that there is no wrong in trying to instill in children a religious doctrine diverse from what their parents wish to have them taught. Still it should not be tried in institutions supported by general taxation.

Thus the reading of the Bible and repeating of the Lord's Prayer, especially with allusion to Christ, even without comment at the opening of school exercises "becomes necessarily devotional and therefore offensive to certain taxpayers." or Jews in self defence against proselyting of their children object to any reading of the Bible-they the very "people of the Book." Religious freedom requires that education on that subject rest exclusively in the churches or.individual homes, where all are free to adopt or reject any belief or faith according to the dictates of conscience. Decisions asserting that rights as Christians are not available to non-believers even as tax payers are especially invidious; thus in Georgia:

"The Jew may complain to the Court as a taxpayer, just exactly when, and only when a Christian may complain as a taxpayer, i.e., when the Legislature authorizes such reading of the Bible or such instruction in the Christian religion in the public schools, as gives one Christian sect a preference over others." 98

Yet again as to the fifty differences between the

96 People v. Graves, 245 N. Y. 195, 156 IN. ‥ 663 (1929).

97 State $\nabla$. Weedman, supra note 91.

- ss See Wilkerson v. City of Rome, supre note 92, at 799, 110 S. E. at 904, quoting from Story. Contra: People v. Board of Education, supre note 91. 
Douai Version of the Bible and the King James version, and the important doctrinal emphasis laid by Catholics on certain passages in the former, omitted or, as alleged, mistranslatedthis is not a matter for consideration of other than ecclesiastical courts, which do not exist as part of our system of jurisprudence. ${ }^{00}$ Roman Catholic parents are offended at the urgence put upon their children to read the Authorized Version, and at their being compelled to hear it read. On the other hand to use the Douai Bible for a like purpose is to the opposite side unthinkable.

The only hope is that sooner or later the question will be settled for all time by the adoption in each state of an aptly worded constitution. The choice here is between such constitutions as that of Mississippi requiring Bible reading in the schools, and of Connecticut, New Hampshire, Vermont, and Massachusetts, giving recognition by name to Christian sects who may teach Christian tenets in public institutions, on the one hand; over against such broader views as that of the constitutions of Louisiana and Ohio requiring the General Assembly to pass suitable laws to protect every religious denomination in the peaceable enjoyment of its own mode of public worship, or that of Illinois, where every person has a natural right to worship God according to the dictates of his conscience. So the free exercise and enjoyment of religious profession and worship without discrimination is provided for in Kentucky and Indiana; and in Kansas no preference to any creed, religious society or mode of worship is set up. . Religious freedom is more surely encouraged by the constitutional provisions of Idaho, where no sectarian or religious tenets or doctrine shall ever be taught in the public schools and no books, tracts or documents denominational in character shall ever be used or introduced in any school, than by the constitutional prescription of Mississippi that "Freedom of conscience hereby secured shall not be construed to exclude the Holy Bible from use in any public school of the State."

The religious controversy being waged daily in a hundred places throughout the country on this narrow question of sectarian instruction in public schools was surpassed in zeal, spleen and the ending of neighborly good will, only by the presidential fight of 1928 into which religious differences were allowed to enter. And it is a fight for. all minorities, with the Jews joining hands with atheists and disbelievers. The history of religious conflicts, always most cruel and protracted (as witness the Thirty Years War) does not permit one to indulge the hope that there will be a slackening of religious zeal..$^{\text {100 }}$

${ }^{90} C$ f. State v. Sheve, supra note 91.

${ }^{200}$ An increasing amount of litigation of the question of sectarian in- 
Veritas vos liberabit. It is certain that the people in every state must be fully enlightened as to these religious proscriptions, by the fullest public discussion, so that a body of interpretive law, may be produced. Then constitutional amendments will follow apace until non-conformists, disbelievers, and religious minorities generally, will have succeeded in procuring recognition of their rightful demands for equal rights before the law.

struction in schools appears in the reports. See summaries in Notes (1920) 5 A. I. R. 866; (1922) 20 A. I. R. 1351; (1924) 31 A. L. R. 1125. Also see Stephens, op. cit. supra note 14. On the general constitutional development of religious liberty, see Reynolds $\nabla$. United States, 98 U. S. 145 (1878), in which IIormonism was discussed. Cf. also Pierce V. Soc. Sisters of Holy Name, 268 U. S. 510, 45 Sup. Ct. 571 (1925), in which a statute requiring compulsory attendance at public schools was held unconstitutional. 